\title{
Dynamics in the Dutch policy advisory system: externalization, politicization and the legacy of pillarization
}

\author{
Caspar F. van den Berg ${ }^{1}$
}

Published online: 14 July 2016

(C) The Author(s) 2016. This article is published with open access at Springerlink.com

\begin{abstract}
Although the literature on policy advisory systems has experienced a revival in recent years, its empirical focus has mainly been on Anglophone countries (Craft and Halligan 2016). This paper applies the policy advisory systems approach to the Netherlands, which can serve as an example of the dynamics in the policy advisory systems of consensus-driven, neo-corporatist polities Lijphart in Patterns of Democracy: Government Forms and Performance in Thirty-Six Countries, 21, 235-266 1999). Using a historical-institutionalist perspective, the dynamics of the Dutch policy advisory system from the mid-1960s to the present day are examined. Based on original cross-time survey data and an analysis of secondary sources, the impact of depillarization (mid-1960s-mid-1990s), new public management (mid-1980s onwards) and an increased pressure on the executive have had for the Dutch policy advisory system (from the late 1990s): fragmentation, externalization and a non-partisan brand of politicization are shown. More specifically, the use of the institutionalized system of permanent advisory councils has lost part of its significance in favour of both external consultants and ad hoc advisory committees. The Dutch case, with its accumulative institutional design based on Weberianism, neo-corporatism and new public management elements, has thus experienced markedly different dynamics in its policy advice system than the Anglophone countries.
\end{abstract}

Keywords Policy advisory systems · Politicization · Public sector reform · The Netherlands · Advisory councils · Consultants · Pillarization

\section{Introduction}

Recent years have seen a revival in the academic interest for policy advisory systems: the increased complexity and interconnectedness of policy challenges, combined with increased political and societal pressures on policy making and implementation, merit a perspective on

Caspar F. van den Berg

c.f.van.den.berg@fgga.leidenuniv.nl

1 Leiden University Institute of Public Administration, Schouwburgstraat 2, 2511 VA The Hague, The Netherlands 
policy advice that is not limited to single actors and organizations, but that instead views the arena of supply and demand for policy advice as a system of interdependent and competing actors and organizations (Scott and Baelher 2010; Craft and Howlett 2013).

Interestingly, much of this new interest has been directed towards the Anglophone world: Britain, Canada, the USA, Australia and New Zealand (Prince 1983; Halligan 1995; Saint-Martin 2005). Much less is known about the evolution of policy advisory systems in non-Anglophone systems over the past decades. At the same time, few efforts have been made to systemize, theorize or explain variation between policy advisory systems across countries or time periods (Hustedt and Veit, this issue).

The present study firstly contributes to the overall purpose of the special issue by giving new insights into the policy advisory system of the Netherlands, a consensus-driven neo-corporatist system in Continental Europe (Lijphart 1999). By focusing on a non-Anglophone system that shares a number of relevant characteristics with various other European countries and by taking a longitudinal perspective that shows a near-cyclical change pattern (Hood 1974), this study fills a gap in the international academic literature on policy advisory systems.

Secondly, this study contributes to tackling the theoretical questions raised in the issue's introductory article regarding the rationalization and legitimization functions of policy advice (Hustedt and Veit, this issue), which can but need not be in opposition to one another (Halffman and Hoppe 2005). This question is of particular relevance for policy advice systems in countries such as the Netherlands, Belgium and Austria. These countries all have strong traditions in consensual and maximum-majority policy making (Daalder 1966). In these systems, the provision of high-level substantive expertise (rationalization) and the representation of different societal groups (legitimization) were institutionally entwined through neo-corporatist structures.

Thirdly, whereas the concept of a policy advisory system encompasses both the more visible actors (such as institutionalized advisory councils, professional policy analysts and NGOs) and the less visible ones, the latter have received strikingly little attention. Among the less visible actors, we count individuals or ad hoc committees who, on a temporary basis, are "hired" by governments as policy or managerial consultants (Beveridge 2012; Howlett and Migone 2013; Van den Berg et al. 2015c; see also Pierre 1998; Boston 1994; Prasser 2006; Fischer 2003). In this contribution, these less visible actors are explicitly included in the analysis.

This paper addresses the following questions: To what extent is the recently revitalized perspective of the advisory systems literature supported or challenged by the Dutch case? What dynamics have shaped and reshaped the Dutch policy advisory system since the 1960s? What factors that have impacted Anglophone systems have also impacted the Dutch system and have the consequences been similar? What have been distinct factors in shaping the Dutch policy advisory system and how have they influenced it?

The remainder of this paper is structured as follows: below is first a brief discussion of the current state of policy advisory systems research ("The current state of policy advisory systems research"), followed by the theoretical expectations guiding this study ("Theoretical framework"). After a concise justification of the research design and the data used ("Research design and data"), the empirical findings will be presented ("Empirical analysis"). It ends with some concluding remarks and suggestions for further research ("Discussion and Conclusion").

\section{The current state of policy advisory systems research}

The notion of a policy advisory system (Halligan 1995) refers to the complex system of actors who cooperate in various ways to provide the advice that helps decision makers shape policies. These actors can be based both within and outside of the government 
apparatus (Mitchell 2005). The configuration of actors and their relationships is unique for each jurisdiction, and within each jurisdiction it may vary from policy sector to policy sector (Seymour-Ure 1987; Halligan 1995; Craft and Howlett 2012). Also, the composition and functioning of a policy advisory system can change over time.

Recent research into policy advisory systems has focused on three main phenomena: externalization, politicization and internationalization. The process of externalization in the policy advice system denotes a general shift away from reliance on the public service to other sources of advice and a professionalization of policy competence outside the public service. In 1995, Halligan noted such a shift was taking place for the Anglophone countries.

The situation was rather different in the 1990s for European continental countries with a corporatist tradition (such as Germany, Austria, the Netherlands and Belgium). In these countries, the more or less institutionalized involvement of established non-government organizations (representative associations, advocacy groups, trade unions) had already been functioning for many decades (see "Empirical analysis" below). For the Netherlands, Halffman and Hoppe (2005) have argued that between the mid-1990s and the mid-2000s, next to the corporatist pattern of the science/policy boundary, two other patterns have gained in prominence, namely the neoliberal and the deliberative pattern.

For Belgium, the findings of Bossens et al. (2014) reconfirm the importance of internal next to external advice seeking and stress how limited the room for change of a policy proposal is, once agreement on it has been reached at the political level. For Flanders, Fobé et al. (2013) have recently found that the reorganization of the regional policy advisory system has not led to a convergence of the structure of advisory councils and that the members of the corporatist advisory councils perceive the influence of their own advice as relatively low. Pattyn et al. (2014) have considered the heterogeneous landscape of Flemish political party study centres, which appear to function more as an extension of political parties than as classical think tanks. The latter is in contrast to recent studies on the German policy advisory system, where the role of political party think tanks, that are publicly funded but whose research programs are completely party-controlled, is unparalleled. The crowded German "policy market" consisting of think tanks and governmental researchers further appears to lead to a "de-parliamentarization" of policy advice in the German system (Siefken 2007; Blum and Schubert 2013).

A second main line of recent research has been the increased politicization of policy advice, as elected political actors have tried to reassert the primacy of politics in the policy process (Daviter 2015; Di Francesco and Eppel 2011; Dahlström et al. 2011; Radin 2013; Savoie 2015). This type of politicization has been seen in the use of political appointees, the political involvement in senior public service staffing, the use of performance management and procedural steering. Additionally, it has also been witnessed in the employment of ministerial entourages consisting of political and special advisors, communication managers and parliamentary liaisons. These ministerial entourages are growing in terms of their size and scope in many countries, and they risk clogging information flows from the departmental policy advisors to the minister (Van den Berg and Dijkstra 2015).

Lastly, internationalization has been a focus of various lines of research into policy advice and policy advisory systems (Craft and Howlett 2012). Internationalization can firstly be seen in the eroding territorial boundaries of the substance of many policy issues. Supranational layers of governance, in particular within the framework of the European Union, allow members of the domestic policy advisory system to increasingly help shape the intergovernmental policy advisory system (Geuijen et al. 2008; Trondal et al. 2008; Braun and Van den Berg 2013). The mechanism is, however, working in both directions: 
members of the supranational policy advisory system also increasingly influence the collective discourse on policy within domestic systems (Forder and Menon 2013; Van den Berg et al. 2015a). Secondly, internationalization is observed through the increasing use by national policy makers of international policy experts and consultants as a source of advice for domestic policy (Adler and Haas 1992; Bakvis 2013; Coen and Thatcher 2008; Eberlein and Newman 2008; Legrand 2012).

Whereas many of the studies from the Anglophone countries have taken an integrated approach to policy advisory systems, the continental European studies discussed above are all partial in the sense that they do not cover the policy advisory system as a whole (with the exception of Bossens et al. 2014). Instead, they focus on one or two types of actors within the policy advisory system. The important gap in the literature is then as follows: what picture emerges if the policy advisory systems approach is applied to a European continental country characterized by (a) a relatively long tradition of large-scale external advising, (b) a considerable degree of politicization of their policy making process in recent years and (c) a relatively high exposure to internationalization due to EU integration? The Netherlands is a system that neatly fits these criteria and is therefore a very suitable setting for investigation.

\section{Theoretical framework}

This study's point of departure is the historical-institutionalist argument which holds that internal and external pressures for change in the medium term lead to absorptions and adjustments that fit within the historical institutional context and within the framework of choices that have been made in the past (North 1990; Arthur 1994; Pierson 2004). In the period 1966-2015, three key phenomena are likely to have influenced the nature and functioning of the Dutch policy advisory system. These are as follows: (a) depillarization, or the dismantling of the pillarized societal and political system (roughly from the mid1960s to the mid-1990s), (b) public sector reforms under the heading of New Public Management, which attempted to modernize public administration by means of introducing more managerial and market-based work processes, privatization and deregulation (from the mid-1980s up to the present) and (c) increased pressure on the executive, due to changes in mass media and communications, increased transparency, expanded auditing, increased competition in the political marketplace and the political polarization of the electorate (from the late 1990s up to the present).

The Dutch pillarized system of consensus politics had its roots in mediaeval times and developed extensively in the seventeenth and eighteenth centuries (Daalder 1966; Hendriks and Toonen 2002). The modern institutionalized system of consensus politics then assumed its shape during the power struggles between the Catholics, Protestants (with two distinct brands, conservative and reformed), Socialists and, albeit reluctantly, Liberals at the beginning of the twentieth century (Rihoux et al. 2015). The system emerged to accommodate potentially disruptive tensions between religious and socio-economic subcultures by means of cooperating according to informal diplomacy-like rules of the game. The system was marked by subcultural segments, or pillars, where (a) the associated political parties defended the pillars' interests and (b) most interestingly for our present purposes, an elaborate system of ancillary organizations (such as trade unions and interest organizations of different types) played a leading role in the representation of the pillars and in cross-pillar elite accommodation. The Dutch version of consensus politics boiled 
down to policy making arrangements "that broaden[ed] the involvement in decisionmaking as widely as possible" and to a political culture that "eschew[ed] decision-making by majority" (Andeweg 2000: 511). It entailed a form of corporatist policy making which in its structure was highly comparable to that of other countries following the Rhineland model (Germany, Switzerland, Belgium and Luxemburg) and to the social partnership and concertation systems seen in Austria, Italy and Ireland (Katzenstein 1985).

After the Second World War, a period of so-called etatization (Van der Meer 2014) took place in the Netherlands. During this period, service delivery and the financing of the pillarized intermediary organizations increasingly became the responsibility of the government, and a wide system of advisory bodies and councils for policy input was set up.

In the mid-1960s, a process of depillarization and a connected erosion of the pillarized intermediary organizations set in (Van der Meer et al. 2012). This dismantling of the pillarized collective advice structures and public service delivery started with the confessional pillars and was more or less completed when the socio-democratic pillar eroded in the 2000s. The pillarized structures reflected a representative and democratically legitimizing system of policy making and service delivery. In the field of service delivery (in areas such as education, health care, etc.), the transformation of the old pillarized organizations into more fragmented intermediary organizations controlled by managers resulted in a considerable loss of legitimacy for these organizations and for the system as a whole (Van der Meer 2014). The impact of depillarization on the policy advisory system has been thought to have been similar to that for the service-delivery landscape: fragmentation and a loss of legitimacy.

In response to the fiscal crisis of the late 1970s and early 1980s, and in order to counter the alleged overstretching and overburdening of the government apparatus in that time, policy initiatives were introduced to reduce the size of the government and enlarge the private (public) domain and the use of new management techniques along the line of the private sector $(N P M)$ were promoted. While the Netherlands was not among the first countries to embrace the principles of NPM, from the late 1980s onwards most of its ideas were turned into reform policies (Pollitt and Bouckaert 2011). Halligan notes at the time that in the Anglophone countries, where New Public Management caught on before it did elsewhere, governments sought "to incorporate special skills by the use of external advisors and as an alternative source to the public service," and that "[p]rivate sector consultants have also flourished in the age of privatization." "More generally," Halligan contends, "under fiscal austerity, governments have sought to reduce staff and functions. Often this has involved the substitution of consultants for public servants because it has been more politically (and managerially) acceptable. As a result, external organizations have been increasingly used for policy design and development" (1995: 154-155).

Therefore, for the Netherlands, too, it is to be expected that for the policy advisory system, New Public Management-style reforms would have led to cutbacks on the elaborate system of advisory bodies and councils and to a preference for hiring external consultants on short-term contracts instead.

It has to be noted that in the case of the Netherlands, as well as in other consensual systems, externalization may have been less straightforward than it was in many more centralized and majoritarian systems, as the traditional system of advisory bodies and councils was already external to the permanent departmental civil service. However, that does not mean that externalization, understood as the outward shift of policy advice, did not take place. Whereas Halligan makes a threefold distinction between the "public service," and advisors who are "internal to government" and "external to government" (1995: 141), to grasp externalization in the Netherlands, we need to take into account the 


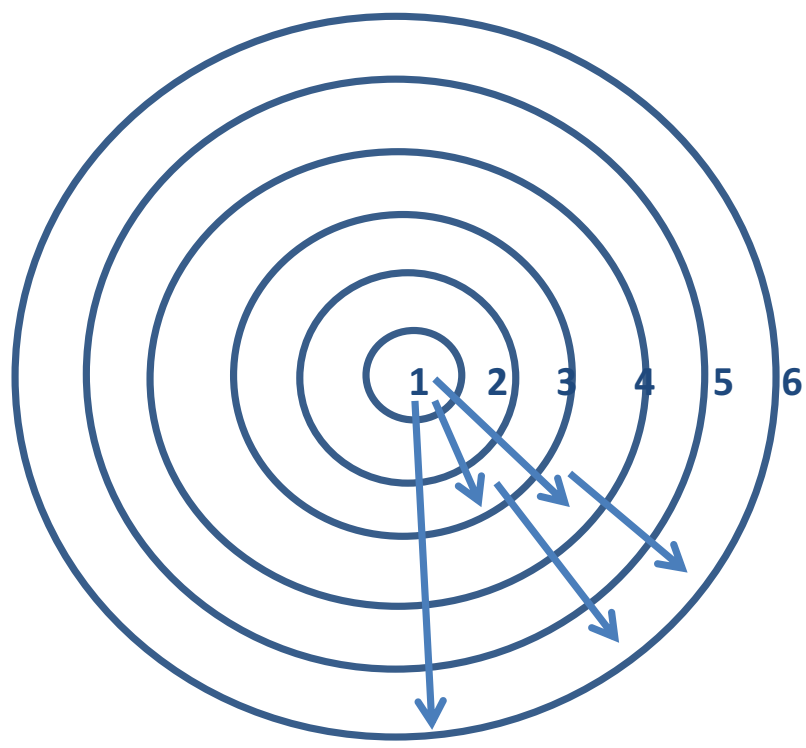

Fig. 1 Public personnel categorized by six circles and the externalization of the policy advisory function Source: developed from Van den Berg et al. (2015c)

typology of public sector employment in Fig. 1, which consists of 6 concentric circles (Van den Berg et al. 2015c). Circle 1 corresponds with Halligan's "public service," circle 3 with advisors "internal to government" (permanent advisory councils), and circles 4 (community organizations subject to public grants) and 6 (external consultants and members of ad hoc advisory committees) would fall under Halligan's advisors "external to government" category.

1. The innermost circle is the core of the public service, that is, the staff employed by general governmental institutions such as the ministerial departments.

2. The second circle consists of personnel employed in independent executive agencies under public law.

3. The third circle contains the staff of permanent advisory councils, and educational and healthcare institutions under public law, including public research institutes, but also universities and other educational institutions under public law, and academic hospitals.

4. The fourth circle consists of the employees in the so-called private-public domain, that is, organizations under private law which are nonetheless funded by public means and are without commercial purpose, and can include foundations, advisory bodies and councils.

5. The fifth circle includes those who are employed in publicly owned companies.

6. The sixth and final circle consists of externally hired staff: those who are employed by a commercial organization under private law, where the government holds no shares and who on the basis of a contract perform tasks for or in name of the government, such as contractors, advisory firms, or catering, cleaning and security firms.

Based on this typology for the Netherlands, it is to be expected that New Public Management would have led to an outward shift from more internally situated circles to more externally situated circles, specifically from 1 to 3 and 4, from 1 to 6 , and from 3 and 4 to 6 . 
This would have corresponded to a decrease in the number of internal policy advisors, a decrease in the use of the system of permanent advisory bodies and councils and an increase in the use of external consultants as policy advisors.

The third major development is the increased pressure on the executive, due to changes in mass media and communications, increased transparency, expanded auditing, increased competition in the political marketplace and the political polarization of the electorate (Aucoin 2012). The result of this in the Anglophone countries has been the risk that ministers "all too easily regard the values of a non-partisan public service and the distinct spheres of authority assigned to public servants as obstacles to be overcome in the pursuit of effective political management" (Aucoin 2012: 186). Advice is decreasingly sought from independent, non-partisan and critical internal or external advisors, and more from sources that can more easily be controlled and who are more likely to advise in ways that help the minister or head of government realize their political strategy by removing and circumventing political and policy obstacles.

In the Netherlands, the political sphere was very stable and predictable in the post-war period: voters voted overwhelmingly for candidates from their own pillars and until 1994 government coalitions always consisted of the Christian Democrats with either the Liberals to the right or the Social Democrats to the left. In 1994 it was the first time in parliamentary history that a government without a Christian democratic party was formed: the liberal socio-democratic government (the Purple Coalition) was in power until 2002. This has since been followed by a period of much greater electoral volatility and increasing societalpolitical pressure on the executive: prematurely falling government coalitions have become the rule rather than the exception, various anti-system protest parties have emerged and won considerable numbers of parliamentary seats, and the party political landscape has become increasingly fragmented. In 2010, for the first time since the Second World War, no majority government could be formed which resulted in a minority cabinet with parliamentary support from the controversial Freedom Party of Geert Wilders. Since 2012 there has been a ruling coalition which holds a majority in only one of the two chambers of parliament, making governance inherently unstable (see Van den Berg and Dijkstra 2015).

Given this increased volatility and pressure on the executive, it is to be expected that in the Netherlands too, there has been a greater demand on the part of politicians to be surrounded and advised by individuals and organizations which are trusted and which can be more easily steered, rather than by permanent civil servants or institutionalized and sheltered permanent advisory bodies and councils. If this is indeed the case, then we should observe a greater use of both political assistants and more ad hoc advisory committees, in lieu of permanent civil service policy analysts and permanent advisory bodies and councils.

Summing up, based on the existing theoretical knowledge, we should expect that the Dutch policy advisory system has experienced the following influences and changes in the period 1966-2015:

Depillarization is likely to have led to an erosion of (a) the representative logic of many advisory bodies and (b) the automatic legitimacy of these bodies, which has subsequently likely to have had a negative impact on their authority and survival.

New public management is likely to have led to a decreasing willingness to financially sustain a wide system of independent, sheltered advisory bodies and has likely favoured the hiring of external, market-based consultants.

The increased pressure on the executive is likely to have led to a stronger demand on the side of executive politicians to control and steer policy advice, which will probably have 
stimulated the use of ad hoc advisory committees and political advisors, and decreased the appeal to and authority of permanent advisory bodies.

\section{Research design and data}

For the investigation of the Dutch policy advisory system in the period from 1960 to the present, we designed a cross-time comparison nested in a single case study (Yin 2014: 51). The purpose of the case study was to assess the extent to which the policy advisory systems approach developed in Anglophone systems is equally helpful for understanding Continental European systems such as the Netherlands. The Netherlands is an important case to study, as it is generally regarded as the oldest and most elaborate example of a consensual political system (O'Leary 2005), and because it is so different regarding relevant structural factors from the Anglophone systems that have predominantly been studied so far. In contrast to the Anglophone systems, the Netherlands is marked by proportional representation, a fragmented multi-party system, a tradition of elite accommodation and a neocorporatist style of policy making.

The Netherlands shares many relevant characteristics with other consensus-driven and neo-corporatist countries, such as Belgium, Germany, Austria and Switzerland. Next to their similarity on most of the abovementioned structural factors, these countries also share with the Netherlands that there is an increasing pressure on the executive. This is at least in part the result of recent populist backlashes, which pose a challenge to the practice of elitebased consensus building (Hackhverdian and Koop 2007). Hence, the research design not only allowed us to draw relevant contrasts with the Anglophone systems, it also opens possibilities for developing theory for further analysis of this wider group of consensusdriven and neo-corporatist countries.

The analysis was based on multiple types of primary and secondary data. The first part of the period was covered by means of an analysis of existing literature where the practices and underlying principles of the Dutch policy advisory system were examined.

In addition, primary data were used, namely a survey instrument developed for senior civil servants, which includes questions on consultation practices with a range of potential external advisors, questions on the relevance of possessing various types of expertise for senior civil servants and questions aimed at the relationships with political advisors. This survey was conducted in 2007 and replicated with the same questions and the same population in 2013. Both the times the survey was conducted on the web.

The survey population consisted of all top managers within the central civil service (secretary-generals, inspector-generals and equivalents, director-generals and directors). Together they form the Dutch senior civil service (Bekker 2015), a group of 996 individuals in 2007, and 802 individuals in 2013. The 2007 survey yielded 418 responses (a response rate of 41.4 per cent), while the 2013 survey yielded 235 responses (a response rate of 29.3 per cent).

Next to the survey data taken from senior civil servants, another survey data set was used, which targeted external policy advisors $(N=378)$. This latter survey research was inspired by the study of Howlett and Migone (2013) on external policy advisors contracted by the Canadian federal government. For our data set, the target population was the consultants contracted by the national civil service for policy-, communication- and legal advice in the period from 2010 to 2012. The details about these advisors were made public by the Dutch Ministry of the Interior following a freedom of information request on 
external contracting by a third party (Ministerie van Binnenlandse Zaken en Koninkrijksrelaties 2013a, b). The list contains 1912 individual potential respondents from 192 unique advisory organizations. For our survey, 378 filled in and submitted their answers, resulting in a response rate of 20 per cent, which is comparable to that of other studies in which external advisors have been surveyed (Colebatch 2006; Howlett and Migone 2013a; Veselý 2013; for more details on the survey, see Van den Berg et al. 2015c). The analysis focused on simple relationships in the data. Moreover, the analysis was supported by semi-structured interview data collected from Dutch senior civil servants in $2007(N=23)$ and $2015(N=15)$.

\section{Empirical analysis}

\section{Pillarization and depillarization}

As pointed out above, the twentieth century Dutch policy advisory system was firmly embedded in the pillarized system of governance that had taken shape between 1875 and 1925. In the wake of the development of the pillarized political parties, policies (notably education) and interest groups, a segmented but proportionally representative policy advisory system came into being.

Next to the internal departmental policy advisory units, this system also included both civil society organizations and policy advisory bodies, such as advisory councils, expert commissions and research organizations. These bodies served among other purposes as permanent contact points for ministers and civil servants in need of (a) input for policies, (b) legitimation and/or (c) implementation capacity. Some organizations leaned more towards an evidence-based and technocratic advisory role (e.g. the Central Planning Bureau), others more towards a deliberative and corporatist role (e.g. the Social-Economic Council) (Mayer 2007), but none were contributing to either policy rationalization or legitimization exclusively. At the central level, numerous councils and commissions, whose members were representatives of interest groups or independent experts, played an important part in building the necessary political consensus and served as "refrigerators when policy issues became too polarized to handle" (Oldersma et al. 1999, 336).

In a number of sectors, particularly in the fields of agriculture, education and health care, ties between the administration and pillarized interest organizations were very close. The leaders of these organizations often shared the same social and educational backgrounds with ministers and senior civil servants. It was not unusual for individuals to move from a position with an interest organization to a position in parliament or the government, or vice versa. While this system ensured effective coordination, it also led to compartmentalization: policy sectors developed into vertical silos within which all relevant organizations used the same jargon and mental frames (Rijnen and Robers-Obbes 1977). This can partly be explained by the fact that civil servants in the Netherlands have typically been trained as specialists in the field of their respective departments, as opposed to the more generalist training of civil servants in Britain and France (Van den Berg 2011).

While many of the important civil society organizations already emerged before the Second World War, the post-war decades saw the rise of many institutions, councils and services that aimed to provide the government and the administration with reliable knowledge about society (e.g. the Central Bureau for Statistics, the Central Planning Bureau, the National Agency for Spatial Planning, the National Institute for Health Care and the Environment, and the Social-Cultural Planning Bureau and the Scientific Council 
for Government Policy) (Hirsch Ballin 1979). Of these especially the Central Planning Bureau has had a large influence on policies over the past decades. The important role of these institutions is an important explanatory factor for the externalization of policy advice even before NPM-style reforms were introduced. In addition, it shows that the Dutch system has long been very open to the international discourse on empiricist and evidencebased understandings of expertise (Hallfman 2009).

\section{Reform and NPM-style externalization}

The degree to which strong cooperation between the administration and these corporatist councils and research organizations is seen as positive has fluctuated over time. Until the 1970 s, the policy advisory system was regarded as highly legitimate, not in the least because of its effectiveness in building consensus and in producing policies that worked economically and socially. In the 1980 s, however, a more critical view dominated, as the strong influence of advisory bodies was seen as insufficiently democratic and as an impediment to economic growth (Lijphart and Crepaz 1991; Smith 1993; Woldendorp 1995).

In the 1980s, the government attempted to curb the influential position of the councils and commissions in response to these criticisms. It has to be noted that concerns about the role of such bodies not only pertained to legitimacy issues, but also to their operating costs and the perception that they were an obstacle to the implementation of austerity policies. Hence, the negative views about the role of advisory bodies should be seen as part of the growing popularity of new public management (NPM) and neoliberal ideas during the course of the 1980s. All of this resulted in a trend to move away from the corporatist involvement of advisory bodies in the years before 1990 (Den Uyl 1978; WRR 1977; Van Delden 1981).

Encouraged by international organizations such as the European Union, the OECD, the IMF and the World Bank, the Netherlands further reformed its public sector in a number of ways in the 1990s, including the privatization of its state-owned enterprises, the creation of executive agencies at arm's length from the smaller central ministries, and a focus shift towards regulatory governance (Pollitt and Bouckaert 2011). In addition to these structural reforms, the 1990s also saw several reforms to the advisory system. These reforms were designed to make "independent expertise" the guiding principle of the advisory system. The dominant function of the advisory system soon became the provision of expertise, rather than the channelling and voicing of pillarized societal interests. Members of advisory committees were, thus, increasingly selected by politicians and civil servants because of their expertise rather than their representative function for a given interest group or constituency (Oldersma et al. 1999).

While the available literature points to a traditionally large degree of external policy advising in the Netherlands, which was reinforced through NPM-style reforms in the 1980s and 1990s (Halffman and Hoppe 2005), systematic quantitative data for the pre-2007 period are not available. ${ }^{1}$ To assess the degree and nature of externalization since 2007, however, we can use primary survey data. We will first look at externalization from circle 1 to circles 3 and 4 , and then at externalization from the more centric circles to circle 6 .

\footnotetext{
${ }^{1}$ Existing studies that cover the pre-2007 period point to a widening of the range of information available for policy makers and fragmentation (Woldendorp 1995; Halffman and Hoppe 2005; Pollitt and Bouckaert 2011; Van der Meer et al. 2012; Dijkstra et al. 2015).
} 
Externalization from circle 1 to circles 3 and 4 refers to a decrease in the use of core civil servants as policy advisors and to an increase in the use of the staff of permanent advisory councils, public research institutes and advisory bodies. Previous studies have pointed to an ongoing decrease in the policy advising capacity of the core civil service since 2003 (Van der Meer et al. 2012; Dijkstra et al. 2015), and the question is whether this has gone hand in hand with an increase in the use of external councils and institutes. For this, we turn to survey data collected in 2007 and 2013. First, we asked senior civil servants on the number of external advice providers of various types they interacted with during the year prior to the survey. Their answers are summarized in Table 1.

These findings point to a clear and across the board increase in the number of organizations within each of the categories of external policy providers in the period 2007-2013. In particular, external research institutes (part of circle 3) seem to have become a more prominent source for policy advice.

Second, survey respondents were asked what type of external actors were their primary sources of expertise. This gives us additional insights in the changes in prominence of organizations in the second and the sixth circle. The results are summarized in Table 2.

These results show that in recent years, across policy domains, research institutes have been the primary source of external expertise, followed by consultancy firms, executive public agencies and advisory councils. While the position of advisory councils overall seems to have stabilized between 2007 and 2013, zooming into policy domains gives a more differentiated picture. While their importance has risen in the economic and financial domain and in the justice and home affairs domain, it has decreased in the international, social, and infrastructure and environment domains.

When it comes to externalization from the more centric circles to circle 6 , two categories of external policy advisers deserve specific attention: ad hoc advisory committees and external consultants. Ad hoc advisory committees stand out because their use signifies a move away from the traditional, institutionalized system of permanent advisory councils in the third circle, and external consultants merit particular consideration because they form the part of the policy advisory system that is less visible-and even less studied-but which has increased in importance during the period studied.

\section{Ad hoc committees}

The relatively low reliance on the expertise of permanent advisory councils reported in Table 2 is in line with various other studies which confirm that the executive prefers temporary advisory committees, rather than permanent institutionalized advisory councils (Schulz et al. 2008, Schulz 2010). The shift from the use of permanent advisory councils to ad hoc committees signifies an externalization from circle 3 to circle 6. Temporary committees have been instituted for a wide variety of issues such as state reforms, biotechnology, energy taxation, private wartime funds, aviation-induced noise disturbances, pesticides and study grants. If controlled for variation caused by election cycles, there has been a steadily growing use of ad hoc advisory committees since 1995 (Schulz et al. 2008: 104). The increased use of such committees can be explained by three key motives (Schulz et al. 2008).

The first is the increased need for specialized expertise, which might not be available within the permanent advisory bodies. This expertise need not necessarily be substantive; it can also be process-related, such as the ability to deal with large political, societal or economic clashes of interest, or social controversy and unrest. 


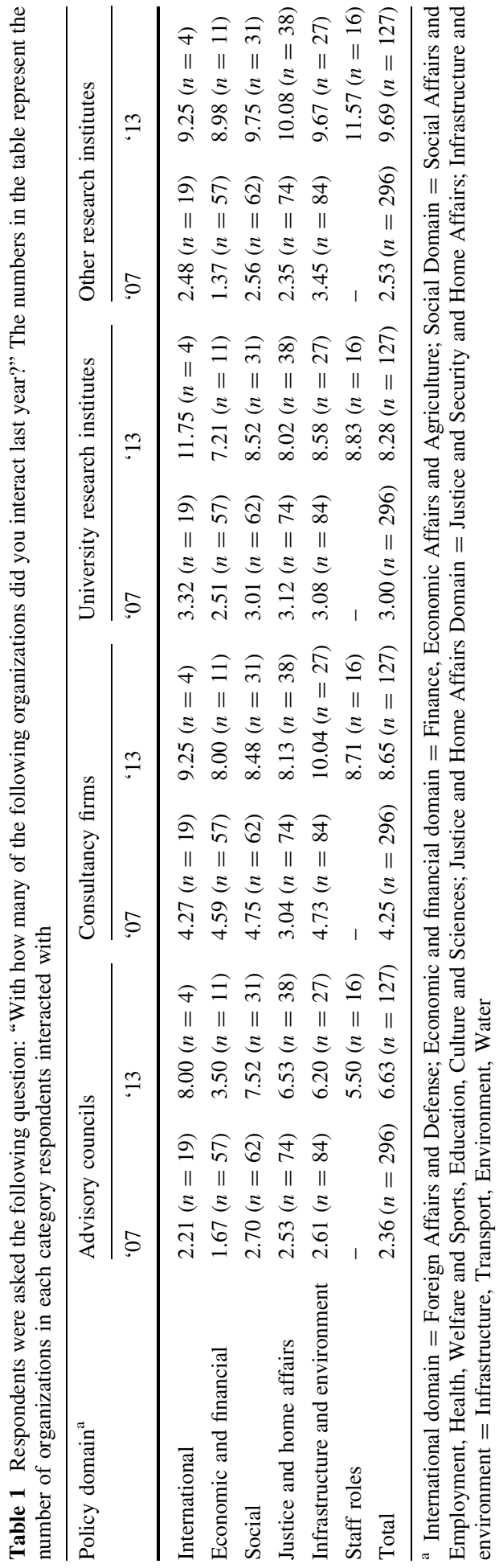




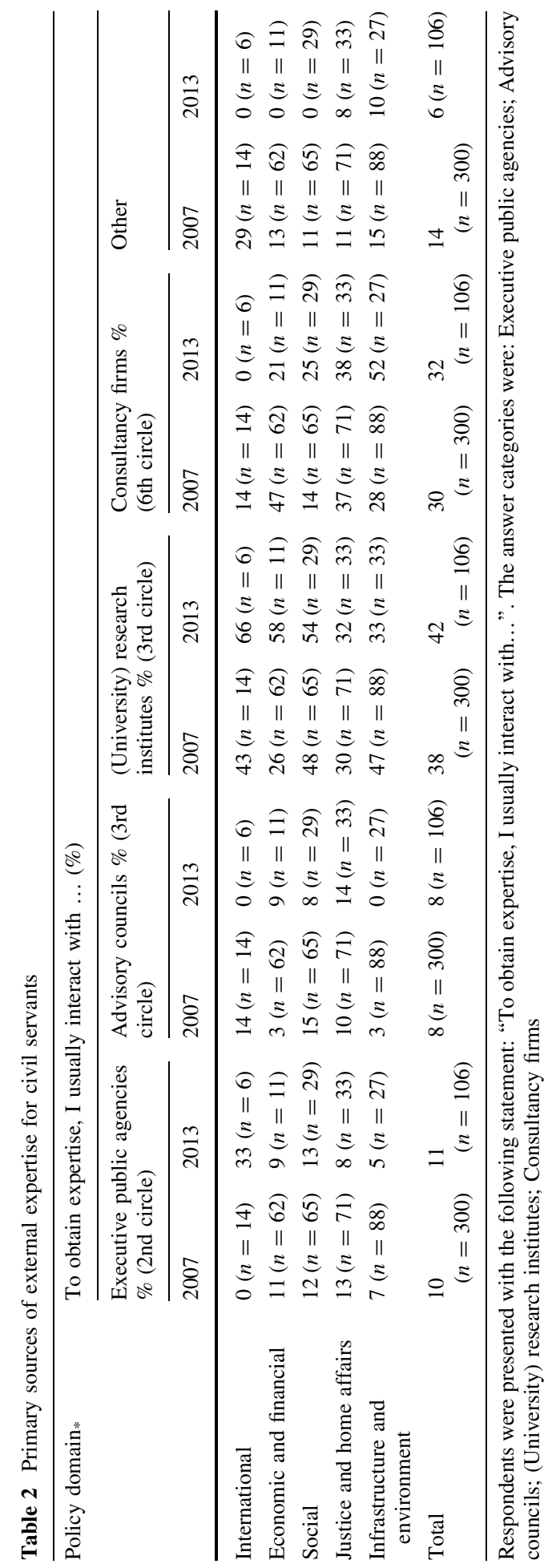


A second explanation for the greater use of ad hoc committees rather than permanent bodies is the desire to secure independence. In specific cases it can be a great asset for the committee and its members to be completely separate from the long-standing advisory structures or the prevailing policy processes. This argument can also conveniently be used if a minister prefers to circumvent the expertise and perspectives that are known to be present within the department or within the permanent advisory body for that policy issue.

A third explanation for the greater use of ad hoc committees is that ministers find them better suited than standing organizations for creating broad political support. This motive corresponds with the original motive for the creation of the system of advisory bodies and councils, but, as explained above, after depillarization the representative credibility of the system decreased and other, differentiated and issue-specific forms of inclusiveness became more effective for the creation of broad support. Schulz et al. (2008) conclude that given both the increased complexity of various policy issues and the increased political pressure on the executive, ministers often feel better served by committees whose composition can be better tailored and more easily controlled than permanent advisory bodies and councils.

\section{External consultants}

The Netherlands has, together with the USA, the highest density of management and policy consulting firms in the world (Rosenthal et al. 1996: 111). Still, thus far the characteristics of consultants and their involvement in the policy advisory system have not been researched. In addition, they are particularly relevant in the context of externalization of policy advice given that they belong to circle 6 , the outermost circle of public personnel. Who are these external consultants? To what extent do they contribute to policy making? And what are the differences among policy sectors and different types of activities? For these questions, we can also rely on original survey data.

External policy consultants are virtually without exception highly educated, as most have an academic ( 84 per cent) or college ( 9 per cent) background. Table 3 shows the distribution across the fields of education of external consultants. Of these consultants, $22 \%$ had previously been employed as a national civil servant, while $20 \%$ had previously been employed as a civil servant at the local level.

In order to determine the degree to which the work of external consultants is processdriven or substance-driven (see Howlett and Migone 2013), respondents were asked about the nature of their activities. The respondents cited 22 different activities in total, and these were clustered into four categories: policy advice, policy implementation, policy evaluation and process support activities, see Table 4.

The results indicate that external consultants are mostly employed to provide policy advice and process support and that they are to a lesser degree involved in policy implementation and policy evaluation. The ministries in which the highest percentage of external consultants is employed to supply policy advice are Social Affairs and Employment (89 per cent), Infrastructure and the Environment (85 per cent) and Public Health, Wellbeing and Sports (84 per cent). The ministries in which external consultants were least often used as policy advisors are Defense (67 per cent) and Economic Affairs (73 per cent). They are also hired relatively less for staff roles (73 per cent). This contrasts to some extent with the findings of Howlett and Migone (2013) for Canada. They found that external consultants are mostly used in process support, while the question about their input in terms of substance remains to some degree unanswered. 
Table 3 Field of education of external consultants hired by Dutch central government organization Source: own data

\begin{tabular}{lr}
\hline Field of education & $\%$ \\
\hline Law & 21 \\
Public administration & 12 \\
Finance/economics/business & 12 \\
Engineering & 11 \\
Social sciences & 11 \\
Communication and media studies & 10 \\
Sciences & 6 \\
Geography & 6 \\
Humanities & 6 \\
Other & 5 \\
Total $(\mathrm{N}=378)$ & 100 \\
\hline
\end{tabular}

\section{Politicization}

An increase in the importance of political considerations in the provision of policy advice can be reflected by (a) an increase in the degree to which political-strategic insight is seen as relevant for the toolbox of the civil service in conjunction with a decrease in the relevance of substantive expertise and (b) an increase in the role of politically appointed ministerial advisers in policy advice.

In our 2007 and 2013 surveys, we asked respondents about the relevance of politicalstrategic insight and substantive expertise for their work. Civil servants should always be able to provide their minister with information on the possible political implications of a given policy proposal or decision, but the degree to which the importance of such political advice (increasingly) outweighs the importance of substantive advising, is an indicator of politicization of their policy advisory role. Overall, in the period 2007-2013 no significant increase in the political nature of civil service work seems to have taken place. Only for the domain of Infrastructure and the Environment, do we see a meaningful increase in the relevance of political-strategic insight. In addition, we do not find a systematic decrease in the relevance of substantive expertise, rather a slight overall increase (see Table 5).

It is also clear that a new type of advisor has emerged in the Dutch policy advisory landscape since the late 1990s: the political assistant to ministers and junior ministers. Their added value is not primarily seen in terms of substantive or technical expertise, but rather in terms of political-strategic advising and network connections vis-à-vis parliamentary factions and the media. The potential downside of the increased number and influence of these actors is that executive strategy is becoming overly political and not sufficiently policy-oriented and that political assistants are focusing too much on the political branding of the minister and too little on the legal and constitutional aspects of policy making, the interests of the organization or policy sector and the coherence of cabinet policy. While there are no official figures, the number of personal advisors, political advisors and press secretaries surrounding ministers and junior ministers has gradually increased over the past 15 years (Nieuwenkamp 2001; Van der Steen et al. 2009; Van den Berg 2011). Their importance and influence has also been measured in the 2013 survey, where respondents were asked about the relevance of political advisors to their work and about their interaction style with these political advisors. The table below summarizes our findings (Table 6). 
Table 4 Involvement of external consultants in various policy and process-related activities, per ministry

\begin{tabular}{|c|c|c|c|c|}
\hline \multirow[t]{2}{*}{ Ministry $^{\mathrm{a}}$} & \multicolumn{4}{|c|}{ Regularly involved in... $(\%)^{\mathrm{b}}$} \\
\hline & $\begin{array}{l}\text { Policy } \\
\text { advice }^{c}\end{array}$ & $\begin{array}{l}\text { Policy } \\
\text { implementation }^{\mathrm{d}}\end{array}$ & $\begin{array}{l}\text { Policy } \\
\text { evaluation }\end{array}$ & $\begin{array}{l}\text { Process } \\
\text { support }^{\mathrm{f}}\end{array}$ \\
\hline Foreign affairs $(n=113)$ & 76 & 61 & 46 & 77 \\
\hline Defense $(n=33)$ & 67 & 43 & 25 & 56 \\
\hline Economic Affairs $(n=93)$ & 73 & 59 & 41 & 78 \\
\hline Finance $(n=165)$ & 80 & 41 & 46 & 79 \\
\hline Social affairs, employment $(n=300)$ & 89 & 45 & 62 & 85 \\
\hline Home affairs $(n=302)$ & 82 & 43 & 52 & 82 \\
\hline Security, justice $(n=267)$ & 79 & 29 & 43 & 71 \\
\hline Public health, wellbeing, sports $(n=287)$ & 84 & 42 & 57 & 82 \\
\hline Education, culture, science $(n=314)$ & 77 & 35 & 53 & 74 \\
\hline Infrastructure, environment $(n=446)$ & 85 & 43 & 42 & 84 \\
\hline Staff roles $(n=373)$ & 73 & 27 & 39 & 72 \\
\hline Unweighted average & 79 & 43 & 46 & 77 \\
\hline
\end{tabular}

a For reasons of comparability, for both the 2007 and the 2013 data, the ministries reflect the combinations of issue areas as they were clustered in the Rutte II government

b "Regularly involved in" is the percentage of respondents that indicated to carry out one or more of the presented tasks under each heading every 3 months, every month, every week or every day. As respondents were asked to answer for as many of the activities that applied, percentages add up to more than 100

c "Policy advice" denotes one or more of the following tasks: (a) gathering policy-related data or information; (b) carrying out policy-related research and analysis; (c) identifying policy options; (d) supplying and/or assessing policy options; (e) carrying out an field analysis; (f) issue-tracking; (g) carrying out a legal analysis; (h) preparing briefing notes or position papers; (i) giving ministerial briefings; (j) formulating policies; (k) drafting reports, presentations or markers for decision makers; (1) consulting decision makers about policy issues

d "Policy implementation" denotes the implementation of policies or policy programs

e "Policy evaluation" denotes one or more of the following tasks: (a) evaluating policy outcomes and results; (b) evaluating policy processes and procedures

f "Process support" denotes one or more of the following tasks: (a) drafting a departmental planning; (b) preparing budget proposals; (c) negotiating with relevant stakeholders on behalf of client; (d) consulting citizens about policy issues; (e) informing departmental management; (f) informing policy advisors; (g) informing external stakeholders

These results indicate that political advisors are important to the work that civil servants do and that cross-sectoral variation is modest. To what extent does the importance for the political advisers also has a politicizing impact on the policy advisory system? Qualitative interviews illustrate the role of political advisors in policy making, and how it has come at the expense of the role of permanent civil service legal advisors. In policy making, more emphasis has come to be placed on the political advisors putting out their feelers and negotiating with the parliamentary factions and much less on the traditional and nonpolitical advice roles such as those of legal and constitutional advisors. Whereas the latter used to be heavily involved from start of the policy process onwards, now their input is often pushed back to the very end of the process when there is little room left for changes (Van den Berg and Dijkstra 2015: 257). So whereas politicization is not so much observed in the work of civil servants per se, political considerations in the policy process seem to have become more pronounced through the work of the minister's direct entourage. 
Table 5 Relevance of "political-strategic insight" and "substantive expertise" as skills for the work of civil servants, by policy sector, 2007 and 2013

\begin{tabular}{|c|c|c|c|c|}
\hline \multirow{3}{*}{ Policy domain } & \multicolumn{4}{|c|}{ Relevance of particular skills to civil servants' work } \\
\hline & \multicolumn{2}{|c|}{ Political-strategic insight } & \multicolumn{2}{|c|}{ Substantive expertise } \\
\hline & 2007 & 2013 & 2007 & 2013 \\
\hline International & $4.94(n=18)$ & $4.7(n=5)$ & $4.39(n=18)$ & $5.00(n=5)$ \\
\hline Economic and financial & $4.76(n=51)$ & $4.85(n=11)$ & $4.18(n=51)$ & $4.91(n=11)$ \\
\hline Social & $4.74(n=53)$ & $4.77(n=32)$ & $4.24(n=53)$ & $4.31(n=32)$ \\
\hline Justice and home affairs & $4.53(n=63)$ & $4.66(n=35)$ & $4.38(n=63)$ & $4.26(n=35)$ \\
\hline Infrastructure and environment & $4.58(n=77)$ & $4.86(n=28)$ & $4.13(n=77)$ & $4.11(n=28)$ \\
\hline Staff roles & - & $4.86(n=7)$ & - & $4.29(n=7)$ \\
\hline Total & $4.66(n=342)$ & $4.76(n=118)$ & $4.24(n=342)$ & $4.32(n=118)$ \\
\hline
\end{tabular}

Respondents were asked the following question: "How relevant is each of the following skills to your current position?" The answers were given on a 5-point Likert scale ranging from 1 (=not relevant at all) to 5 (=very relevant)

Table 6 Relevance of political advisors to civil servants' work

\begin{tabular}{ll}
\hline Policy domain* & $\begin{array}{l}\text { Relevance of political advisors to } \\
\text { respondent's work (2013) }\end{array}$ \\
\hline International & $4.75(n=4)$ \\
Economic and financial & $4.28(n=11)$ \\
Social & $4.23(n=31)$ \\
Justice and home affairs & $4.00(n=36)$ \\
Infrastructure, environment & $3.93(n=28)$ \\
Staff roles & $4.00(n=7)$ \\
Other & $3.75(n=16)$ \\
Total & $4.05(n=133)$ \\
\hline
\end{tabular}

Respondents were asked the following question: "How relevant is each of the following external actors to your current position?" The answers were given on a 5-point Likert scale ranging from 1 (=not relevant at all) to 5 (=very relevant)

\section{Discussion and conclusion}

This analysis has shown how the demand for external policy advice has changed in the Netherlands over the last five decades, in response to shifting demands. While our research approach and data do not give a complete basis for definitive conclusions, our evidence seems to point at four main trends. First, the demand for substantive expertise to legitimize government decisions was strongest in the post-war decades and has been declining somewhat from the mid-1970s onwards. Second, the demand for interest representation to legitimize government decisions was strong throughout the pillarized era and has started to decline in the mid-1960s. Third, the demand for substantive expertise to fill in for internally lost know-how has been gaining in importance from the 1990s onwards. And fourth, 
the demand for external opinions to counter displeasing internal and external policy opinions appears to have been growing from the 2000s onwards.

It has also been shown that the notion that external policy advice may serve either to rationalize government decisions or to legitimize them (Veit and Hustedt, this issue) is of limited applicability for the case of the Netherlands. Even though the relative weight of various types of policy advice providers has been variable and fluid across time, the same advice providers have consistently been used to both rationalize and legitimize government policies. In this sense, at least for the Netherlands, there does not seem to be a natural contrast between the rationalization and legitimation of policies through policy advice, a finding that is supported by the literature on the science-policy nexus and on "civic epistemologies" (Hoppe 2005; Jasanoff 2005; Hilgartner et al. 2015).

The first part of the empirical analysis explains how, notwithstanding slight but discernible fluctuations, over the past 50 years a shift has taken place from a stable and institutionalized, pillarized consensus-generating policy advisory system to a more politicized, flexible and ad hoc policy advisory system. For the pillarized advisory councils of the post-war decades, the primary aim was to give high-quality substantive input in the policy process, and the means by which this was achieved was by composing the councils of experts that collectively formed a proportional reflection of the pillarized society. By combining expertise and proportionality, the system helped to both rationalize and legitimize government decisions. While not empirically part of this analysis, it is to be expected that this combination of expertise and proportionality has been important in other consensus-oriented neo-corporatist systems such as Belgium, Germany and Austria.

Since the post-war decades, the Dutch policy advisory system has changed in the sense that the uncontested reliance on the wide system of advisory councils has made way for a more fluid, ad hoc and fragmented system, where policy advice is mainly acquired from temporary consultants and ad hoc advisory committees. The internal bureaucratic advisory capacity has decreased from the 1980 s onwards as a result of the austerity measures and the outward orientation that came along with NPM reforms.

Parallel to this, the perceived legitimizing capacity of the advisory councils went down in the 1980s, rose again in the 1990s and was somewhat discredited again in the 2000s. The influence and prestige of the traditional, institutionalized policy advisory bodies has eroded from the 1980s onwards, and various of these bodies and councils have either been abolished, merged with others or shrunk in size. This can be explained both by the decrease in the legitimacy, representativeness and effectiveness of the elaborate advisory system after depillarization, and by the perceptions of the high operational costs of these bodies in response to fiscal tightness and New Public Management ideas. Interestingly, however, the degree to which these institutionalized advisory bodies are consulted by senior civil servants for policy advice seems to have remained relatively stable.

At the same time, it appears that decreases in the availability of internal policy advice as well as decreases in the perceived appropriateness of policy advice from the institutionalized advisory councils have been absorbed by an increase in the hiring of external consultants (externalization). Evidence therefore seems to suggest that the policy advisory capacity from (a) internal civil servants, (b) institutionalized advisory councils and (c) external consultants have been communicating vessels for most of the period studied. The one exception appears to be the period after the most recent economic crisis (2009-2013).

All in all, it seems that the observed externalization and politicization of the Dutch policy advisory system can be understood against the backdrop of socio-political (depillariziaton and increased pressure on the executive) and economic-political (NPM) factors 
and that at least for the Netherlands, the dynamics in the policy advisory system cannot be seen in isolation from general public sector reforms. While both the externalization and politicization of the policy advisory system have been observed for the Anglophone countries, the legacy of pillarization and consensus-oriented policy making has produced a different dynamics in the Dutch case. The differences concern timing, rhetoric and substance.

The timing has been different given that the Anglophone countries embarked on NPMstyle reforms of their public sectors roughly five to ten years before the Netherlands (Pollitt and Bouckaert 2011). This means that the start of the more or less systematic erosion of internal policy capacity set in earlier too (Craft and Halligan 2016). The rhetoric has been different in the sense that in the Anglophone countries political leadership called for policies and policy processes that were more inclusive and participatory with societal and business partners under the heading of Third Way politics. In the Netherlands, just like in other neo-corporatist countries, the rhetoric of the Third Way resonated much less given that it was a continuation of its traditional policy making model (Christensen and Yesilkagit 2006).

Lastly, the substance has been different in the sense that whereas for the Anglophone systems a spectrum ranging from the internal (public service) to the external (private sector) is a helpful analytical tool, for the Netherlands the essence of the policy advisory system is to be found between three poles, that of the internal civil service, the institutionalized system of neo-corporatist advisory bodies and the private sector. Over the past decades, the policy advisory system has variously tilted more to one or two of these poles, but none of the poles have ever really been marginalized.

The developments in the Dutch policy advisory system considered in this study reflect a pluralization of the policy advisory landscape over time. The evidence for the Netherlands seems to point at a policy advisory system that is a highly dynamic arrangement. In this arrangement, multiple ideas about what good policy making is conflict with one another and vie for dominance, resulting in different outcomes at different points in time. This competition of ideas is mirrored in the types of actors that alternate as preferred sources of policy advice. The core theoretical finding therefore is the need for a smaller emphasis on stability and structure, and a greater acknowledgement of the dynamic nature of policy advisory systems.

Acknowledgement This publication has been made possible by support from the Netherlands Organization for Scientific Research (NWO), Grant 016.155.098.

Open Access This article is distributed under the terms of the Creative Commons Attribution 4.0 International License (http://creativecommons.org/licenses/by/4.0/), which permits unrestricted use, distribution, and reproduction in any medium, provided you give appropriate credit to the original author(s) and the source, provide a link to the Creative Commons license, and indicate if changes were made.

\section{References}

Adler, E., \& Haas, P. M. (1992). Conclusion: Epistemic communities. World Order, and the Creation of a Reflective Research Program International Organization, 46(2), 367-390.

Andeweg, R. B. (2000). Consociational Democracy Annual Review of Political Science, 3, 509-536.

Arthur, W. B. (1994). Increasing returns and path dependence in the economy. Ann Arbor: University of Michigan Press.

Aucoin, P. (2012). New political governance in westminster systems: Impartial public administration and management performance at risk. Governance, 25(2), 177-199. 
Bakvis, H. (2013). In the shadows of hierarchy: Intergovernmental governance in Canada and the European Union. Canadian Pubic Administration, 56(2), 203-218.

Bekker, R. (2015). Politicians and civil servants: Cycling in Tandem. In J. Uijlenbroek (Ed.), Dutch public service: Organisation and functioning of the government in the Netherlands, the position of civil servants and the main developments. The Hague: CAOP.

Beveridge, R. (2012). Consultants, depoliticization and arena-shifting in the policy process: Privatizing water in Berlin. Policy Sciences, 45, 47-68.

Blum, S., \& Schubert, K. (Eds.). (2013). Policy analysis in Germany. Bristol: Policy Press.

Bossens, N., Van Damme, J., \& Brans, M. (2014) Beleidsadvisering in de Vlaamse overheid. Een analyse van de organisatie van de Vlaamse beleidsadvisering en een verkenning van mogelijkheden voor optimalisering, Leuven: Steunpunt Bestuurlijke Organisatie-Slagkrachtige Overheid.

Boston, J. (1994). Purchasing policy advice: The limits of contracting out. Governance, 7(1), 1-30.

Braun, C., \& van den Berg, C. F. (2013). At a snail's pace: On the limited europeanization of domestic consultation practices. Public Administration, 91(3), 763-781.

Christensen, J. G., \& Yesilkagit, K. (2006). Delegation and specialization in regulatory administration: A comparative analysis of Denmark, Sweden and The Netherlands. In T. Christensen \& P. Lægreid (Eds.), Autonomy and regulation (pp. 203-234). Cheltenham: Edward Elgar.

Coen, D., \& Thatcher, M. (2008). Network governance and multi-level delegation: European networks and regulatory agencies. Journal of Public Policy, 28(1), 49-71.

Colebatch, H. K. (2006). What work makes policy? Policy Sciences, 39(4), 309-321.

Craft, J. \& Halligan, J. (2016). Assessing 30 years of Westminster policy advisory system experience. Policy Sciences. doi:10.1007/s11077-016-9256-y.

Craft, J., \& Howlett, M. (2012). Policy formulation, governance shifts and policy influence: Location and content in policy advisory systems. Journal of Public Policy, 23(2), 79-98.

Craft, J., \& Howlett, M. (2013). The dual dynamics of policy advisory systems: The impact of externalization and politicization on policy advice. Policy and Society, 32, 187-197.

Daalder, H. (1966). The Netherlands: Opposition in a segmented society. In R. A. Dahl (Ed.), Political opposition in Western Democracies. New Haven: Yale University Press.

Dahlström, C., Peters, B. G., \& Pierre, J. (2011). Steering from the centre: Strengthening political control in Western Democracies. Toronto: University of Toronto Press.

Daviter, F. (2015). The political use of knowledge in the policy process. Policy Sciences, 48, 491-505.

Den Uyl, J. M. (1978). Die tijd komt nooit meer terug. In H. Daudt \& E. van der Wolk (Eds.), Bedreigde Democratie: Parlementaire Democratie en Overheidsbemoeienis in de Economie (pp. 37-56). Assen: Intermediair.

Di Francesco, M., \& Eppel, E. (2011). A public management heresy? Exploring the managerial role of ministers in public management policy design. In B. Ryan \& D. Gill (Eds.), Future state: Directions for public management in New Zealand (pp. 123-158). Wellington: Victoria University Press.

Eberlein, B., \& Newman, A. (2008). Escaping the International Governance Dilemma? Incorporated Transgovernmental Networks in the European Union Governance, 21(1), 25-52.

Fischer, F. (2003). Reframing public policy: Discursive politics and deliberative practices. Oxford: Oxford University Press.

Fobé, E., Brans, M., Vancoppenolle, D., \& Van Damme, J. (2013). Institutionalized advisory systems: An analysis of member satisfaction of advice production and use across nine strategic advisory councils in Flanders (Belgium). Policy \& Society, 32(3), 225-240.

Forder, J., \& Menon, A. (Eds.). (2002). The European Union and National macroeconomic policy. Abingdom: Routledge.

Geuijen, K., Hart, P. T., Princen, S. \& Yesilkagit, K. (Eds.). (2008). The new Eurocrats. Amsterdam: Amsterdam University Press.

Hackhverdian, A., \& Koop, C. (2007). Consensus democracy and support for populist parties in Western Europe. Acta Politica, 42, 401-420.

Halffman, W., \& Hoppe, R. (2005). Science/policy boundaries: A changing division of labour in Dutch expert policy advice. In S. Maasen \& P. Weingart (Eds.), Democratization of expertise? Exploring novel forms of scientific advice in political decision-making (pp. 135-151). Berlin: Springer Verlag.

Hallfman, W. (2009). Measuring the stakes: The Dutch planning bureaus. In P. Weingart \& J. Lentsch (Eds.), Scientific advice to policy making: International comparison (pp. 41-66). Opladen: Barbara Budrich Publishers.

Halligan, J. (1995). Policy advice and the public service. In B. G. Peters \& D. T. Savoie (Eds.), Governance in a Changing Environment (pp. 138-172). Montreal: McGill-Queen's University Press.

Hendriks, F., \& Toonen, T. A. J. (Eds.). (2002). Polder politics in The Netherlands: The Reinvention of Consensus Democracy in The Netherlands. Farnham: Ashgate. 
Hilgartner, S., Miller, C., \& Hagendijk, R. (Eds.). (2015). Science and democracy: Making knowledge and making power in the biosciences and beyond. London: Routledge.

Hirsch Ballin, E. H. M. (1979). Publiekrecht en beleid: Fundamentele kwesties rondom het functioneren van de Wetenschappelijke Raad voor het Regeringsbeleid. Alphen aan den Rijn: Samsom/Tjeenk Willink.

Hood, C. (1974). Administrative diseases: Some types of dysfunctionality in administration. Public Administration, 52, 439-454.

Hoppe, R. (2005). Rethinking the science-policy nexus: From knowledge utilization and science technology studies to types of boundary arrangements. Poiesis \& Praxis, 3(3), 199-215.

Howlett, M., \& Migone, A. (2013). The search for substance: Externalization, politicization and the work of Canadian policy consultants 2006-2013. Central European Journal of Public Policy, 7, 1.

Jasanoff, S. (2005). Designs on nature: Science and democracy in Europe and the United States. Princeton: Princeton University Press.

Katzenstein, P. (1985). Small states in world markets: Industrial policy in Europe. Ithaca: Cornell University Press.

Legrand, T. (2012). The merry mandarins of Windsor: Policy transfer and transgovernmental networks in the Anglosphere. Policy Studies, 33(6), 523-540.

Lijphart, A. (1999). Patterns of democracy: Government forms and performance in thirty-six countries. Hew Have: Yale University Press.

Lijphart, A., \& Crepaz, M. M. L. (1991). Notes and comments: Corporatism and consensus democracy in eighteen countries; conceptual and empirical linkages. British Journal of Political Science, 21, 235-256.

Mayer, I. S. (2007). Evolution of policy analysis in The Netherlands. In F. Fischer, G. Miller, \& M. Sidney (Eds.), Handbook of public policy analysis (pp. 553-570). Boca Raton: Taylor \& Francis.

Ministerie van Binnenlandse Zaken en Koninkrijksrelaties (2013a). Externe inhuur BZK 2013.

Ministerie van Binnenlandse Zaken en Koninkrijksrelaties (2013b). Beslissing op uw Wob-verzoek.

Mitchell, D. (2005). Centralizing advisory systems: Presidential influence and the US foreign policy decision-making process. Foreign Policy Analysis, 1(2), 181-206.

Nieuwenkamp, R. (2001). De Prijs van het Politieke Primaat. Delft: Eburon.

North, D. (1990). Institutions, institutional change and economic performance. Cambridge: Cambridge University Press.

Oldersma, J., Portegijs, W., \& Janzen-Marquard, M. (1999). The iron ring in Dutch politics revisited. Public Administration, 77, 335-360.

Pattyn, V., Van Hecke, S., Brans, M., \& Libeer, T. (2014). Tussen politieke partijen en think tanks. Een verkennende analyse van de Vlaamse partijstudiediensten. Res Publica, 3, 293-316.

Pierre, J. (1998). Public consultation and citizen engagement: Dilemma's for policy advice. In B. G. Peters \& D. Savoie (Eds.), Taking stock: Assessing public sector reforms (pp. 137-163). Ottawa: Canadian Centre for Management Development.

Pierson, P. (2004). Politics in time: History, institutions, and social analysis. Princeton: Princeton University Press.

Pollitt, Ch., \& Bouckaert, G. (2011). Public management reform: A comparative analysis (3rd ed.). Oxford: Oxford University Press.

Prasser, S. (2006). Royal commissions and public enquiries in Australia. Sydney: Lexis Nexis.

Prince, M. J. (1983). Policy advice and organizational survival: Policy planning and research units in British government. Aldershot, Hampshire: Gower.

Radin, B. A. (2013). Policy analysis reaches midlife. Central European Journal of Public Policy, 7(1), 8-26.

Rihoux, B., Spretizer, A., \& Koole, R. (2015). The impact of Euroepan intergartion on within-party organization dynamics: More of less consensus politics? In. In H. Vollaard, J. Beyers, \& P. Dumont (Eds.), European integration and consensus politics in the low countries (pp. 69-91). London: Routledge.

Rijnen, A Ch M, \& Robers-Obbes, H. G. (1977). Externe adviesorganen van de centrale overheid in Engeland, West-Duitsland, België en Frankrijk. In A Ch M Rijnen \& H. G. Robers-Obbes (Eds.), Adviseren aan de overheid (pp. 55-118). The Hague: Staatsuitgeverij.

Rosenthal, U., Ringeling, A. B., Bovens, M. A. P., Hart, P. T., \& van Twist, M. J. W. (1996). Openbaar Bestuur: Beleid Organisatie en Politiek (5th ed.). Alphen aan den Rijn: Samson Tjeenk Willink.

Saint-Martin, D. (2005). The politics of management consulting in public sector reform. In E. Ferlie, L. Lynn, \& C. Pollitt (Eds.), Oxford handbook of public management (pp. 84-1056). Oxford: Oxford University Press.

Savoie, D. (2015). The Canadian public service: In search for a new equilibrium. In A. Massey \& K. Johnson (Eds.), The International handbook of public administration and governance (pp. 182-198). Cheltenham: Edward Elgar. 
Schulz, M. (2010). De Commissie: Over de politiek-bestuurlijke logica van een publiek geheim. The Hague: Boom Lemma.

Schulz, M., van Twist, M., \& Geveke, H. (2008). Besturen in Commissie: Verklaring van een Fenomeen. In Beleid \& Maatschappij $n r ., 2,94-106$.

Scott, C., \& Baelher, K. (2010). Adding value to policy analysis and advice. Kensington: University of New South Wales Press.

Seymour-Ure, C. (1987). Institutionalization and informality in advisory systems. In W. Plowden (Ed.), Advising the rulers (pp. 175-184). Hoboken: Blackwell Publishing.

Siefken, S. (2007). Expertenkommissionen im politischen Prozess. Eine Bilanz zur rot-grunen Bundesregierung 1998-2005. Wiesbaden: VS.

Smith, M. J. (1993). Pressure, power and policy: State autonomy and policy networks in Britain and the United States. New York: Harvester Wheatsheaf.

Trondal, J., van den Berg, C. F., \& Suvarierol, S. (2008). The compound machinery of government: The case of seconded officials in the European commission. Governance, 21(3), 253-274.

Van Delden, A Th. (1981). Adviesorganen: Rapport over het onderzoek naar het stelsel en het functioneren van externe adviesorganen van de rijksdienst. Den Haag: Staatsuitgeverij.

Van den Berg, C. F. (2011). Transforming for Europe: The reshaping of national Bureaucracies in a system of multi-level governance. Leiden: Leiden University Press.

Van den Berg, C. F., \& Dijkstra, G. S. A. (2015). Wetgevingsjuristen ten prooi aan New Political Governance? Een inventarisatie (2002-2015). RegelMaat, 30(4), 247-266.

Van den Berg, C. F., Braun, C., \& Steen, T. P. S. (2015a). Consensus politics as administrative practice: The europeanization of external advice-seeking? In H. Vollaard, J. Beyers \& P. Dumont (Eds.), European integration and consensus politics in the low countries (pp. 114-134). London: Routledge.

Van den Berg, C. F., van der Meer, F. M., van Mannekes, M., van Osch, D., Porth, J., \& Schmidt, A. (2015b). Koers houden in turbulentie: De rol van de rijksoverheid op het gebied van infrastructuur en milieu internationaal vergeleken. Den Haag: CAOP.

Van den Berg, C. F., Schmidt, A., \& van Eijk, C. (2015c). Externe advisering binnen de Nederlandse overheid: Naar een empirisch en theoretisch onderbouwde onderzoeksagenda. Bestuurskunde, 24(3), 17-31.

Van der Meer, F. M. (2014). Minder overheid, maar wie denkt er na over de lange termijn?, Mejudice, (November 18).

Van der Meer, F. M., Raadschelders, J. C. N., \& Kerkhoff, A. D. N. (2012). Van nachtwakersstaat naar waarborgstaat. Proliferatie en vervlechting van het Nederlandse openbaar bestuur in de lange twintigste eeuw (1880-2005). In F. P. Wagenaar, M. R. Rutgers, \& A. D. N. Kerkhoff (Eds.), Duizend jaar openbaar bestuur in Nederland: Van patrimoniaal bestuur naar waarborgstaat (pp. 221-290). Bussum: Coutinho.

Van der Steen, M., van Twist, M., Peters, R., \& de Vries, M. (2009). Strategiseren in de Schaduw van de Macht: Politiek Assistenten van Bestuurders als Verborgen Verbinders. The Hague: NSOB.

Veselý, A. (2013). Conducting large N Surveys on policy work in Bureaucracies: Some methodological challenges and implications from the Czech Republic. Central European Journal of Public Policy, $7(2), 88-113$.

Wetenschappelijke Raad voor het Regeringsbeleid. (1977). Adviseren aan de overheid. Den Haag: Staatsuitgeverij.

Woldendorp, J. J. (1995). Neo-corporatism as a strategy for conflict regulation in the Netherlands. Acta Politica, 2, 212-252.

Yin, R. K. (2014). Case study research: Design and methods (5th ed.). London: Sage. 